\title{
Relationship between psychosocial factors and musculoskeletal disorders in footwear industry workers
}

\author{
Jonhatan Magno Norte da Silva ${ }^{\mathrm{a}, \mathrm{b}}$, Luiz Bueno da Silva ${ }^{\mathrm{c} *}$, Leila Amaral Gontijo \\ aUniversidade Federal de Santa Catarina, Florianópolis, SC, Brazil \\ bUniversidade Federal de Alagoas, Delmiro Gouveia, AL, Brazil \\ 'Universidade Federal da Paraíba, João Pessoa, PB, Brazil \\ *bueno@ct.ufpb.br
}

\begin{abstract}
This study evaluated the effects of psychosocial factors on the risk of WRMD symptoms in Brazilian footwear industry workers. The workers' perceptions regarding psychosocial factors and frequency of body pain were collected through a self-administered questionnaire. Logistic regression modeling was used to estimate the risk (Odds Ratio) of a worker more frequently exhibiting a symptom due to psychosocial factors. It was observed that some psychosocial factors, such as stress, contribute to WRMD in men, increasing the chance of symptoms in the knee (OR=3.07; $p$-value $=0.036)$. In women, the 'job dissatisfaction' factor contributes to WRMD, increasing the chance of pain in the elbow (OR=4.83; $\mathrm{p}$-value $=0.007$ ). It was concluded that a greater number of psychosocial factors influences the development of WRMD in male workers, although the effect these factors be discreet. In women, less psychosocial factors are related to WRMD, however its influence is very significant.
\end{abstract}

Keywords

Industrial ergonomics. Musculoskeletal discomfort. Work conditions. Gender differences.

How to cite this article: Silva, J. M. N., Silva, L. B., \& Gontijo, L. A. (2017). Relationship between psychosocial factors and musculoskeletal disorders in footwear industry workers. Production, 27, e20162315. http://dx.doi.org/10.1590/01036513.231516

\section{Introduction}

Work-related musculoskeletal disorders (WRMDs) are changes, caused or made worse by work, in many different types of tissue in the human body, such as muscles, ligaments and joints (Siegel, 2007; European Agency for Safety and Health at Work, 2008; Widanarko et al., 2011). In Brazil, expenditure on WRMDs has risen to R\$ 356 million per year (Moraes \& Bastos, 2013). Companies have reported more than 15,000 occupational diseases to the Ministry of Social Security (Brasil, 2013). Of these, approximately 60\% were some type of musculoskeletal disorder.

Reducing the incidence of WRMDs is a major challenge for researchers in ergonomics because their origin is more related to biomechanical factors, such as repetitive movements, excessive force and awkward postures (Fernandes \& Fernandes, 2011), but also cognitive, social, environmental, organizational and psychosocial factors (Kuorinka \& Forcier, 1995; Couto \& Moraes, 2003; Solidaki et al., 2010; Widanarko et al., 2014). The Biopsychosocial Model (Melin \& Lundberg, 1997) is an accepted model in the scientific community to explain the origin of WRMDs. This model considers psychosocial factors as one possible causes of musculoskeletal disorders (Leka et al., 2011).

According to the European Agency for Safety and Health at Work (2014), psychosocial factors arise from the poor organization and management of work, which may entail a lack of social support, psychological aggression, conflicting demands and an imbalance in the work-family relationship. Such factors contribute the worker to 
feel dissatisfied, stressed and demotivated, and this phenomenon is reflected in expenditures on the order of 240 billion Euros per year on medical treatment and production losses.

Bernard (1997), Leka et al. (2011), lavicoli et al. (2011), and Hauke et al. (2011) emphasized that there are few studies on the effects of psychosocial factors on WRMDs even in developed countries. This limitation hinders the introduction of remedial actions and health and safety policies aimed at combating these factors, which would lead to more effective workplace interventions that could minimize psychosocial risk. However, to properly establish the relationship between psychosocial factors and occupational hazards present in the workplace, other studies should also be conducted in developing countries so that the effects of these factors on WRMD symptoms can be better understood (Mehrdad et al., 2010; Kortum et al., 2011; Widanarko et al., 2015).

The Biopsychosocial Model explains the likelihood of WRMDs appearing in the human body due to increasing stress levels experienced by workers when faced with an aggressive stimulus, can be psychosocial risks. The ability of such individuals to adapt to the adverse situation determines their response to the situation: workers either learn to cope, which increases their ability to maintain stable stress levels in future hostile situations, or experience reduced health due to increased production of stress hormones and their metabolites in the body's muscles and cells, which contributes muscle tension, increased perception of effort and workload in industrial activities, increased sensitivity to pain and susceptibility to muscle injuries (Lundberg et al., 1989; Bathman et al., 2013). Nicot (2007) observed that industrial workers experience a high level of stress. In addition, Govindu \& Babski-Reeves (2014) state that the presence of psychosocial factors can influence changes in the posture, movements and forces exerted by contributing to the WRMD.

The footwear industry historically has negative numbers as regarding the occurrence of WRMDs in workers (Roquelaure et al., 2002). The literature contains several studies indicating that WRMDs affect almost every body part of workers in this industry, including the arm (Amano et al., 1988), the neck (Serratos- Perez \& Mendiola-Anda, 1993), the shoulder (Descatha et al., 2004; Leclerc et al., 2004), the hand/finger (Gupta \& Mahalanabis, 2006), the elbow (Descatha et al., 2007), the upper back (Aghili et al., 2012), the lower back (Warnakulasuriya et al., 2012), the knee (Dianat \& Salimi, 2014), the hip/thigh and ankle/foot (Silva et al., 2016). In addition, the Brazilian footwear industry is marked by a history of physical and psychological violence perpetrated by supervisors against shop floor workers (Borsoi et al., 2009; Rigotto et al., 2010). Previous studies in footwear industries have evaluated the influence of few psychosocial factors in WRMDs or did not consider their impact on the various parts of the body. The collinearity and outlier analyses of independent variables of regression models is not considered in these studies; and the relationship between psychosocial factors and WRMDs is analyzed only by chi-squared test or Fisher Exact test, t-test or multiple linear regressions. In addition, they built models without separating men and women.

Other studies have indicated that different results are found for men and women regarding the relationship between psychosocial factors and WRMD (Roquelaure et al., 2002; Yu et al., 2012; 2013; Barbosa et al., 2013; Petit et al., 2014). Although it is not a consensus in the literature the studies in developed countries attributes to four variables the differences in symptoms of men and women: (1) Biological differences; (2) The increased propensity of women to report symptoms of pain; (3) Women perform household chores and child care that are sources of risk; and (4) work situations are more precarious for women (Wijnhoven et al., 2006). Most studies show that women are more vulnerable to psychosocial factors, however, some recent studies have shown exceptions to this generalization (Clays et al., 2007; Ghaffari et al., 2008; Hooftman et al., 2009). Findings of Kääriäl et al. (2011) shows that industrial male workers is a group prone to developing injuries.

Therefore, the aim of this study was to evaluate the influence of psychosocial risk factors in the work-related musculoskeletal disorders (WRMDs) in men and women of the footwear industry. We chose to analyze the results obtained considering gender differences, because results of the Govindu \& Babski-Reeves (2014) indicate that gender alone is not a risk factor for WRMD, but when analyzed together with other risk factors may have influence significant negative in worsening of WRMDs symptoms.

\section{Methods}

This study was conducted in a footwear company located in the northeast of Brazil, specifically in footwear component preparation and component assembly sections. Data was collected between May and December of 2015. 


\subsection{Sample and procedures}

The data were obtained from 267 production workers, 143 males and 124 females, whose main function was operating machinery and using tools in the manufacture of footwear. Individually, the workers completed the questionnaires during working hours in an air-conditioned room with no outside interference. Before the questionnaires were distributed, one of the researchers read the research consent form to the worker and explained the research objectives. After the worker signed the consent form, the researcher remained in the room to assist him with any questions.

\subsection{Demographic variables}

Information regarding gender, age, length of service in the company, smoking, alcohol consumption, physical activity, education level, civil status and whether they had children were collected from the workers. Height and weight data were also collected to calculate the body mass index (BMI).

\subsection{Physical variables}

Two physical factors were evaluated. Through Job Content Questionnaire (JCQ) (Karasek et al., 1985) was calculated the score for the latent variable 'physical demands', considering the sum of factor analysis weights widely accepted by the scientific community. It was also rated the 'effort' factor through items the Effort-Reward Imbalance Questionnaire (ERI) (Siegrist, 1998), considering the sum the points assigned to each question. Respectively, the mean and median scores were used to dichotomize the perception of workers regarding "physical demands' and 'effort' (Souza et al., 2010).

\subsection{Psychosocial evaluation}

Psychosocial factors were evaluated using the JCQ, the ERI and items based on 'job dissatisfaction' studies by ljzelenberg et al. (2004); studies of 'stress' by Smith et al. (2000); and studies addressing 'bullying', 'sexual harassment', 'discrimination', 'physical violence' and 'monotony' by Niedhammer et al. (2012).

The JCQ dimensions enable measurements of 'job control', 'low social support from co-workers', 'low social support from supervisors', 'psychological demands' and 'job insecurity'. Scores for each latent JCQ variable were based on Karasek et al. (1985), considering the sum of factor analysis weights widely accepted by the scientific community. The median JCQ dimension scores were used to dichotomize each dimension into high or low exposure to psychosocial factors (Souza et al., 2010). Regarding ERI dimensions, the psychosocial factors 'reward' and 'overcommitment' were evaluated. The workers' perceptions were calculated by adding the points assigned to each question; the higher the score is, the lower the reward or the greater overcommitment perceived (Souza et al., 2012). The median ERI questionnaire dimension scores were used to dichotomize each dimension into high or low exposure to psychosocial factors (Souza et al., 2010).

A 4-point likert scale (strongly disagree, disagree, agree and strongly agree) was used for the JCQ and ERl questions. For the psychosocial factors 'job dissatisfaction', 'bullying', 'sexual harassment', 'discrimination', 'physical violence' and 'monotony', a 2-point scale (disagree and agree) was used. A 2-point scale (stressful work and it's not stressful work) was also used for the stress factor.

\subsection{Evaluation of WRMD symptoms}

An adapted version of the Nordic Questionnaire (NQ) (Kuorinka et al., 1987) with a 4-point Likert scale was used to evaluate the occurrence of WRMD symptoms. The body parts evaluated by the NQ include the neck, the upper back, the lower back, the shoulder, the elbow, the forearm, the wrist, the hand, the hip/thigh, the knee, and the ankle/foot. To evaluate the occurrence of symptoms, the workers rated pain by assigning 1 to 4 points (no pain, rarely feels pain, often feels pain and always feels pain).

\subsection{Statistical procedures}

Software R version 3.3.2 (R Core Team, 2016) was used for statistical analysis. The constructs of the research instruments (questionnaires) were validated using Cronbach's $\alpha$ coefficient. A descriptive analysis of demographic data, psychosocial factors and data regarding WRMD symptoms was performed to characterize the study sample 
and perform a preliminary evaluation of symptoms in the workers' different anatomical regions. The collinearity between the variables was verified through the variance inflation factor (VIF).

The outliers have been identified, however, these points are excluded from the analysis only if we convinced that they are leverage points. According to Cordeiro \& Demétrio (2008) the observations are considered inconsistent if the standardized residuals outside the range [-2,2], and also are considered influential if the leverage parameter estimates is greater than ' $2 p / n$ ', where ' $n$ ' is the sample size and ' $p$ ' is the number of independent variables. Inconsistent and influential observations are called leverage points, whose behavior differs significantly from others' model points and may compromise the estimates of the regression model parameters, resulting in a model that does not represent well the trend of relationship between dependent and independent variables.

The ordinal logistic regression models were structured to express the risk (Odds Ratio, OR) of a worker report more frequent pain (musculoskeletal symptoms) due to a psychosocial factor (independent variables). The ordinal logistic regression associating the pain symptoms in different regions of the human body were formulated according to Equation 1:

$$
F=e^{\beta_{0 j}} * \prod_{p=1}^{P}\left[\prod_{s=1}^{4} e^{\left(\beta_{s p}\right)^{P F_{p}}}\right] * \prod_{r=1}^{R}\left[\prod_{t=1}^{4} e^{\left(\lambda_{t r}\right)^{P H_{t r}}}\right] * \prod_{q=1}^{Q}\left[\prod_{k=1}^{K} e^{\left(\gamma_{k q}\right)^{F H_{q q}}}\right]
$$

where $F$ is the OR of the frequency of WRMD symptoms; $j$ is the frequency of pain $(j=1$, 'no pain'; $j=2$, 'occasional pain'; $\mathrm{j}=3$, 'frequent pain'; and $\mathrm{j}=4$, 'everyday pain'); $e^{\beta_{0 j}}$ is the intercept for each $\mathrm{j} ; e^{\beta_{\text {sp }}}$ is the $\mathrm{OR}$ associated with category $s$ ( $s=1$, 'fully disagree'; $s=2$, 'disagree'; $s=3$, 'agree'; and $s=4$, 'fully agree'), which is associated with the psychosocial factor $\mathrm{p}$; $\mathrm{P}$ is the $\mathrm{i}$-th psychosocial factor; PFsp is the category s of psychosocial factor $\mathrm{p} ; \mathrm{e}^{\lambda_{m}}$ is the OR associated with category $t(t=1$, 'fully disagree'; $t=2$, 'disagree'; $t=3$, 'agree'; and $t=4$, 'fully agree'), which is associated with physical factor $r$ of the model fit; $\mathrm{R}$ is the $\mathrm{i}$-th physical factor; PHtr is the category $t$ of physical factor $r$; $e^{\gamma_{k}}$ is the OR associated with category $k$, which is associated with the individual factor $q$ of the model fit; and Flkq is the category $k$ of the individual factor $q$.

The models could be fitted for individual factors as follows: 'length of service' ( $q 1 k) ; k=1$ ( $<12$ months), $\mathrm{k}=2$ (13 to 60 months), $\mathrm{k}=3$ (61 to 120 months), $\mathrm{k}=4$ (181 to 240 months), and $\mathrm{k}=5$ (>240 months); 'age' (q2k); k=1 (18 to 20 years), k=2 (21 to 30 years), $k=3$ (31 to 40 years), $k=4$ (41 to 50 years), and $k=5$ ( $>50$ years); 'body mass index' (q3k); $k=1$ (normal weight), $k=2$ (underweight), $k=3$ (overweight), $k=4$ (obesity type 1), k=5 (obesity type 11), and k=6 (obesity type 111); 'smoking' (q4k); k=1 (smoker) and $\mathrm{k}=2$ (non-smoker); 'drinking habits' (q5k); $\mathrm{k}=1$ (consumes alcohol) and $\mathrm{k}=2$ (does not consume alcohol); 'physical activity' (q6k); k=1 (performs physical exercise) and $k=2$ (does not perform physical exercise); 'civil status' (q7k); k=1 (single) and k=2 (married); 'the presence of children' (q8k); k=1 (has children) and k=2 (does not have children); and 'education level' (q9k); k=1 (elementary l), k=2 (elementary 11), k=3 (high school), $\mathrm{k}=4$ (incomplete higher education), and $\mathrm{k}=5$ (complete higher education).

As for the validity of generalized linear regression models, such as the ordinal logistic regression model, Cordeiro \& Demétrio (2008) emphasize that if the likelihood ratio presents a favorable result for the model under investigation, then the model is reasonably fit to the data and the model can be considered adequate to analyze the relationship between dependent variable and independent variables. Although these authors claim that the identification of leverage points and the likelihood ratio test is sufficient to ensure the validity of the ordinal logistic regression model, it is always useful to verify the goodness of fit measures to understand how well this model describes the relationship between dependent and independent variables. The measure that can be used is model accuracy. Given the values of independent variables, this measure consists of making the classification of observations (the level of pain predicted by the model) and compare with the observed responses (level of pain workers reported). The percentage of correct classifications is the model accuracy. However, for ordinal logistic regression models it is necessary to look carefully at this measure, because high accuracy indicates that the model is really good for assessing the relationship between variables, but a low accuracy does not necessarily indicate otherwise. For this reason, the observation indicated by Cordeiro \& Demétrio (2008) about the likelihood ratio test and leverage points should be considered when evaluating the consistency of ordinal logistic regression models. 


\subsection{Ethics}

This project was approved by the Research Ethics Committee of the Health Sciences Center, Federal University of Paraiba (Universidade Federal da Paraíba - UFPB). The project identification number was CAAE 46893215.1.0000.5188.

\section{Results}

The questionnaire was validated with a Cronbach's alpha value of $0.75(0.70-0.86 ; 95 \% \mathrm{Cl})$, indicating some internal consistency for the construct (Maroco \& Garcia-Marques, 2013). The data showed a normal distribution for BMl only ( $p$-value=0.1809), justifying the use of nonparametric tests to establish independence between genders. Most factors presented VIF near 1, being the highest value for the factor 'low social support from supervisors' with $\mathrm{VIF}=8.2101$. Leverage points were identified in worker responses, reducing the sample size to 264 individuals.

\subsection{Descriptive analysis of individual factors}

Table 1 shows the demographic data. Male workers were concentrated in the 21- to 30-year-old range, and females were concentrated in the 31- to 40-year-old range. The variable 'BMl' showed differences between the genders, with $4.20 \%$ of men and 18.18\% of women being the obese type 1, 11 or 111. Regarding the 'length of service' variable, there was a difference between the genders: 20,66\% of women and 9.09\% of men had performed their duties for longer than 120 months. Regarding the presence of children, a difference was found between the genders, with $70.35 \%$ of women and $37.06 \%$ men having children.

Table 1. Results regarding workers' demographic data.

\begin{tabular}{|c|c|c|c|c|c|c|c|c|c|}
\hline & \multicolumn{2}{|c|}{ Men } & \multicolumn{2}{|c|}{ Women } & & \multicolumn{2}{|c|}{ Men } & \multicolumn{2}{|c|}{ Women } \\
\hline & $\mathrm{N}^{\circ}$ & $\%$ & $\mathrm{~N}^{\circ}$ & $\%$ & & $\mathrm{~N}^{\circ}$ & $\%$ & $\mathrm{~N}^{\circ}$ & $\%$ \\
\hline \multicolumn{10}{|l|}{ Demographic data } \\
\hline Age & & & & & Length of service & & & & \\
\hline $18-20$ years & 41 & 28.67 & 13 & 10.74 & $\leq 12.0$ months & 46 & 32.17 & 13 & 10.74 \\
\hline 21-30 years & 71 & 49.65 & 37 & 30.58 & 13-60 months & 75 & 52.45 & 65 & 53.72 \\
\hline $31-40$ years & 19 & 13.29 & 51 & 42.15 & 61-120 months & 9 & 6.29 & 18 & 14.88 \\
\hline 41-50 years & 8 & 5.59 & 15 & 12.40 & 121-180 months & 2 & 1.40 & 5 & 4.13 \\
\hline$>50$ years & 4 & 2.80 & 5 & 4.13 & $181-240$ months & 8 & 5.59 & 13 & 10.74 \\
\hline BMl $\left(\mathrm{kg} / \mathrm{m}_{2}\right)$ & & & & & $\geq 241$ months & 3 & 2.10 & 7 & 5.79 \\
\hline Underweight & 8 & 5.59 & 6 & 4.96 & Physical activity & & & & \\
\hline Normal weight & 77 & 53.85 & 53 & 43.80 & Yes & 53 & 37.06 & 88 & 72.73 \\
\hline Overweight & 52 & 36.36 & 40 & 33.06 & No & 90 & 62.94 & 33 & 27.27 \\
\hline Type 1 obesity & 6 & 4.20 & 19 & 15.70 & Presence of children & & & & \\
\hline Type 11 obesity & 0 & 0.00 & 1 & 0.83 & Yes & 53 & 37.06 & 88 & 70.25 \\
\hline Type 111 obesity & 0 & 0.00 & 2 & 1.65 & No & 90 & 62.94 & 36 & 29.75 \\
\hline Use of cigarettes & & & & & Education level & & & & \\
\hline Smoker & 13 & 9.09 & 7 & 5.79 & Elementary 1 & 2 & 1.41 & 2 & 1.65 \\
\hline Non-smoker & 130 & 90.91 & 114 & 94.21 & Elementary 11 & 16 & 11.19 & 3 & 2.48 \\
\hline Use of alcohol & & & & & High school & 115 & 80.42 & 109 & 90.08 \\
\hline Yes & 102 & 71.33 & 96 & 79.34 & Incomplete higher ed. & 8 & 5.59 & 5 & 4.13 \\
\hline No & 41 & 28.67 & 25 & 20.66 & Complete higher ed. & 2 & 1.40 & 2 & 1.65 \\
\hline \multicolumn{10}{|l|}{ Civil status } \\
\hline Married & 69 & 48.25 & 67 & 55.37 & & & & & \\
\hline Single & 74 & 51.75 & 54 & 44.63 & & & & & \\
\hline
\end{tabular}

\subsection{Evaluation of physical and psychosocial factors}

Table 2 shows workers' perceptions with regard to the physical and psychosocial factors, respectively. None of the physical factors analyzed showed a sharp difference between men and women. Among the psychosocial factors examined, only 'low social support from co-workers' showed a difference between the genders, with $47.11 \%$ of women reporting that they did not receive advice at work from co-workers. 
Table 2. Results regarding physical and psychosocial factors by gender.

\begin{tabular}{|c|c|c|c|c|c|c|c|c|}
\hline & \multicolumn{4}{|c|}{ Women } & \multicolumn{4}{|c|}{ Men } \\
\hline & Yes & $\%$ & No & $\%$ & Yes & $\%$ & No & $\%$ \\
\hline \multicolumn{9}{|l|}{ Physical factors' } \\
\hline Physical demands & 95 & 78.51 & 26 & 21.49 & 112 & 78.32 & 31 & 21.68 \\
\hline Effort & 51 & 42.15 & 70 & 57.85 & 74 & 51.75 & 69 & 48.25 \\
\hline \multicolumn{9}{|l|}{ Psychosocial factors' } \\
\hline Control over one's work & 75 & 61.98 & 46 & 38.02 & 99 & 69.23 & 44 & 30.77 \\
\hline Psychological demands & 67 & 55.37 & 54 & 44.63 & 98 & 68.53 & 45 & 31.47 \\
\hline Job insecurity & 66 & 54.55 & 55 & 45.45 & 85 & 59.44 & 58 & 40.56 \\
\hline Low support from supervisors & 72 & 59.50 & 49 & 40.50 & 73 & 51.05 & 70 & 48.95 \\
\hline Low support from co-workers & 64 & 52.89 & 57 & 47.11 & 105 & 73.43 & 38 & 26.57 \\
\hline Reward & 58 & 47.93 & 63 & 52.07 & 67 & 46.85 & 76 & 53.15 \\
\hline Overcommitment & 79 & 65.29 & 42 & 34.71 & 80 & 55.94 & 63 & 44.06 \\
\hline Job satisfaction & 51 & 42.15 & 70 & 57.85 & 69 & 48.25 & 74 & 51.75 \\
\hline Physical violence & 4 & 3.31 & 117 & 96.69 & 2 & 1.40 & 141 & 98.60 \\
\hline Sexual harassment & 10 & 8.26 & 111 & 91.74 & 13 & 9.09 & 130 & 90.91 \\
\hline Bullying & 14 & 11.57 & 107 & 88.43 & 25 & 17.48 & 118 & 82.52 \\
\hline Monotony & 102 & 84.30 & 19 & 15.70 & 115 & 80.42 & 28 & 19.58 \\
\hline Discrimination & 13 & 10.74 & 108 & 89.26 & 16 & 11.19 & 127 & 88.81 \\
\hline Stress & 77 & 63.64 & 44 & 36.36 & 83 & 58.04 & 60 & 41.96 \\
\hline
\end{tabular}

\subsection{Evaluation of WRMD symptoms'}

Table 3 shows the responses of workers' regarding the frequency of symptoms'. There were differences between the genders regarding the frequency of WRMD symptoms in the following regions: the neck and the upper back. A higher percentage of women (18.18\%) than men (5.59\%) reported feeling 'everyday pain' in the neck region. Regarding the upper back region, approximately $20.66 \%$ of women and $10.49 \%$ of men indicated 'always feeling pain' in this region of the body.

Table 3. Results regarding frequency of WRMD symptoms'.

\begin{tabular}{|c|c|c|c|c|c|c|c|c|c|}
\hline & \multicolumn{2}{|c|}{ Men } & \multicolumn{2}{|c|}{ Women } & & \multicolumn{2}{|c|}{ Men } & \multicolumn{2}{|c|}{ Women } \\
\hline & $\mathrm{N}^{\circ}$ & $\%$ & $\mathrm{~N}^{\circ}$ & $\%$ & & $\mathrm{~N}^{\circ}$ & $\%$ & $\mathrm{~N}^{\circ}$ & $\%$ \\
\hline Neck & & & & & Shoulder & & & & \\
\hline No pain & 90 & 62.94 & 62 & 51.24 & No pain & 67 & 46.85 & 57 & 47.11 \\
\hline Occasional pain & 17 & 11.89 & 13 & 10.74 & Occasional pain & 27 & 18.88 & 11 & 9.09 \\
\hline Frequent pain & 28 & 19.58 & 24 & 19.83 & Frequent pain & 27 & 18.88 & 29 & 23.97 \\
\hline Everyday pain & 8 & 5.59 & 22 & 18.18 & Everyday pain & 22 & 15.38 & 24 & 19.83 \\
\hline Upper back & & & & & Lower back & & & & \\
\hline No pain & 74 & 51.75 & 68 & 56.20 & No pain & 66 & 46.15 & 59 & 48.76 \\
\hline Occasional pain & 17 & 11.89 & 10 & 8.26 & Occasional pain & 19 & 13.29 & 11 & 9.09 \\
\hline Frequent pain & 37 & 25.87 & 18 & 14.88 & Frequent pain & 32 & 22.38 & 21 & 17.36 \\
\hline Everyday pain & 15 & 10.49 & 25 & 20.66 & Everyday pain & 26 & 18.18 & 30 & 24.79 \\
\hline Elbow & & & & & Forearm & & & & \\
\hline No pain & 127 & 88.81 & 97 & 80.17 & No pain & 107 & 74.83 & 88 & 72.73 \\
\hline Occasional pain & 3 & 2.10 & 6 & 4.96 & Occasional pain & 8 & 5.59 & 4 & 3.31 \\
\hline Frequent pain & 9 & 6.29 & 13 & 10.74 & Frequent pain & 16 & 11.19 & 21 & 17.36 \\
\hline Everyday pain & 4 & 2.80 & 5 & 4.13 & Everyday pain & 12 & 8.39 & 8 & 6.61 \\
\hline Wrist & & & & & Hand/finger & & & & \\
\hline No pain & 68 & 47.55 & 51 & 42.15 & No pain & 85 & 59.44 & 74 & 61.16 \\
\hline Occasional pain & 16 & 11.19 & 13 & 10.74 & Occasional pain & 11 & 7.99 & 12 & 9.92 \\
\hline Frequent pain & 27 & 18.88 & 31 & 25.62 & Frequent pain & 29 & 20.28 & 21 & 17.36 \\
\hline Everyday pain & 32 & 22.38 & 26 & 21.49 & Everyday pain & 18 & 12.59 & 14 & 11.57 \\
\hline Hip & & & & & Knee & & & & \\
\hline No pain & 118 & 82.52 & 97 & 80.17 & No pain & 118 & 82.52 & 90 & 74.38 \\
\hline
\end{tabular}


Table 3. Continue...

\begin{tabular}{|c|c|c|c|c|c|c|c|c|c|}
\hline & \multicolumn{2}{|c|}{ Men } & \multicolumn{2}{|c|}{ Women } & & \multicolumn{2}{|c|}{ Men } & \multicolumn{2}{|c|}{ Women } \\
\hline & $\mathrm{N}^{\circ}$ & $\%$ & $\mathrm{~N}^{\circ}$ & $\%$ & & $\mathrm{~N}^{\circ}$ & $\%$ & $\mathrm{~N}^{\circ}$ & $\%$ \\
\hline Occasional pain & 11 & 7.69 & 6 & 4.96 & Occasional pain & 6 & 4.20 & 3 & 2.48 \\
\hline Frequent pain & 9 & 6.29 & 12 & 9.92 & Frequent pain & 12 & 8.39 & 19 & 15.70 \\
\hline Everyday pain & 5 & 3.50 & 6 & 4.96 & Everyday pain & 7 & 4.90 & 9 & 7.44 \\
\hline \multicolumn{10}{|l|}{ Ankle/Foot } \\
\hline No pain & 87 & 60.84 & 67 & 55.37 & & & & & \\
\hline Occasional pain & 9 & 6.29 & 14 & 11.57 & & & & & \\
\hline Frequent pain & 22 & 15.38 & 20 & 16.53 & & & & & \\
\hline Everyday pain & 25 & 17.48 & 20 & 16.53 & & & & & \\
\hline
\end{tabular}

\subsection{Psychosocial factors' and pain symptoms'}

Table 4 shows the model to estimate the influence of psychosocial factors' in the WRMDs. In general, a greater number of psychosocial factors contributed to the onset of WRMD symptoms in different regions of the body for male workers. The dash (-) in Table 4 indicates that the psychosocial factor was associated with WRMD in only one gender. However, although a smaller number of factors led to the occurrence of WRMD symptoms in women, these factors were associated the emergence of more significant pain.

In general, the models' accuracy presented reasonably high values. Those used to assess the WRMD symptoms in the elbows and forearms presented a rate of correct classifications superior to 70\%. Among men, the models constructed for the forearm, hip and knee region shown rate higher of 82\%. However, some models had an accuracy of less than $70 \%$, although the likelihood ratio test indicates that they are sufficient to evaluate the significance of the effects of each independent variable.

Table 4. Model expressing the chance of developing musculoskeletal symptoms' in eleven body regions.

\begin{tabular}{|c|c|c|c|c|c|c|c|c|}
\hline & \multicolumn{4}{|c|}{ Women } & \multicolumn{4}{|c|}{ Men } \\
\hline & OR & (IL-SL) & p-value & Accu. & OR & (IL-SL) & $\mathrm{p}$-value & Accu. \\
\hline \multicolumn{9}{|l|}{ Neck } \\
\hline Low support from supervisors & 1.35 & $(1.15-1.58)$ & 0.000 & $57.38 \%$ & 1.34 & $(1.06-1.58)$ & 0.001 & $65.25 \%$ \\
\hline Discrimination & 4.70 & $(1.45-15.27)$ & 0.010 & & - & - & - & \\
\hline Stress & - & - & - & & 2.28 & $(1.05-4.95)$ & 0.036 & \\
\hline \multicolumn{9}{|l|}{ Shoulder } \\
\hline Psychological demands & - & - & - & $49.18 \%$ & 1.13 & $(1.03-1.25)$ & 0.009 & $49.65 \%$ \\
\hline Low support from supervisors & - & - & - & & 1.35 & $(1.17-1.56)$ & 0.000 & \\
\hline Low support from co-workers & 1.47 & $(1.03-2.12)$ & 0.036 & & - & - & - & \\
\hline Job dissatisfaction & 3.01 & $(1.32-6.84)$ & 0.009 & & - & - & - & \\
\hline Monotony & - & - & - & & 3.05 & $(1.31-7.09)$ & 0.009 & \\
\hline \multicolumn{9}{|l|}{ Upper back } \\
\hline Psychological demands & - & - & - & $58.20 \%$ & 1.10 & $(1.01-1.20)$ & 0.044 & $51.06 \%$ \\
\hline Low support from supervisors & - & - & - & & 1.19 & $(1.03-1.37)$ & 0.016 & \\
\hline Low support from co-workers & 1.53 & $(1.04-2.26)$ & 0.030 & & - & - & - & \\
\hline Job dissatisfaction & 2.78 & $(1.18-6.58)$ & 0.018 & & - & - & - & \\
\hline \multicolumn{9}{|l|}{ Lower back } \\
\hline Stress & - & - & - & $59.84 \%$ & 2.40 & $(1.28-4.56)$ & 0.007 & $46.10 \%$ \\
\hline Overcommitment & 1.26 & $(1.11-1.43)$ & 0.000 & & - & - & - & \\
\hline Job dissatisfaction & 3.40 & $(1.64-7.07)$ & 0.001 & & - & - & - & \\
\hline \multicolumn{9}{|l|}{ Elbow } \\
\hline Psychological demands & - & - & - & $77.87 \%$ & 1.25 & $(1.07-1.47)$ & 0.005 & $88.65 \%$ \\
\hline Job dissatisfaction & 4.83 & $(1.54-15.13)$ & 0.007 & & - & - & - & \\
\hline \multicolumn{9}{|l|}{ Forearm } \\
\hline Job insecurity & - & - & - & $70.49 \%$ & 1.64 & $(1.17-2.29)$ & 0.004 & $75.18 \%$ \\
\hline Job dissatisfaction & 3.44 & $(1.28-9.24)$ & 0.014 & & - & - & - & \\
\hline Wrist & & & & & & & & \\
\hline
\end{tabular}

OR: Odds Ratio; lL: Inferior limit; SL: Superior Limit; Accu: Accuracy. 
Table 4. Continue...

\begin{tabular}{|c|c|c|c|c|c|c|c|c|}
\hline & \multicolumn{4}{|c|}{ Women } & \multicolumn{4}{|c|}{ Men } \\
\hline & OR & (1L-SL) & $\mathrm{p}$-value & Accu. & OR & (IL-SL) & $\mathrm{p}$-value & Accu. \\
\hline Psychological demands & - & - & - & $42.62 \%$ & 1.14 & $(1.05-1.25)$ & 0.002 & $52.48 \%$ \\
\hline Job dissatisfaction & 2.75 & $(1.40-5.42)$ & 0.003 & & 1.89 & $(1.01-3.57)$ & 0.048 & \\
\hline \multicolumn{9}{|l|}{ Hand/finger } \\
\hline Psychological demands & - & - & - & $62.30 \%$ & 1.11 & $(1.01-1.23)$ & 0.024 & $60.28 \%$ \\
\hline Discrimination & 4,95 & $(1.53-16.04)$ & 0.008 & & - & - & - & \\
\hline Stress & - & - & - & & 2.95 & $(1.46-5.99)$ & 0.003 & \\
\hline \multicolumn{9}{|l|}{ Hip } \\
\hline Bullying & - & - & - & - & 5.30 & $(2.07-13.54)$ & 0.000 & $82.27 \%$ \\
\hline \multicolumn{9}{|l|}{ Knee } \\
\hline Stress & - & - & - & - & 3.07 & $(1.08-8.76)$ & 0.036 & $82.98 \%$ \\
\hline \multicolumn{9}{|l|}{ Ankle/Foot } \\
\hline Low support from supervisors & 1.22 & $(1.06-1.41)$ & 0.006 & $54.10 \%$ & - & - & - & $60.28 \%$ \\
\hline Stress & - & - & - & & 2.15 & $(1.07-4.32)$ & 0.032 & \\
\hline
\end{tabular}

OR: Odds Ratio; IL: Inferior limit; SL: Superior Limit; Accu: Accuracy.

\section{Discussion}

According to the results psychosocial factors influence the WRMD symptoms, increasing the frequency at which these symptoms occur. However, this influence is different in men and women.

\subsection{Symptoms in the regions of the neck, back and lower back}

Some factors, such as 'stress' among men, was associated witch WRMD symptoms in the neck and lower back regions. Hannan et al. (2005), Van den Heuvel et al. (2005), Rugulies \& Krause (2005), Mehrdad et al. (2010), and Widanarko et al. (2014) found sufficient evidence that this factor contributed to the occurrence of WRMD symptoms in the neck. In the same way that study, Greiner \& Krause (2006) showed that stress contributed to symptoms in the lower back. Azagba \& Sharaf (2011) found that psychosocial factors such as 'stress' created increased demand for health services.

Among women, the 'discrimination' and 'job dissatisfaction' factors was associated witch WRMD symptoms in the neck and the lower back, respectively. Hultin et al. (2011), and Niedhammer et al. (2012) suggest that both health problems and problems related to absenteeism may be related to historical discrimination (Lu et al., 2014). The findings of $\mathrm{Yu}$ et al. (2012), and Yue et al. (2014) emphasized that the 'job dissatisfaction' factor had a strong effect on the development of WRMD symptoms in the lower back region among women.

Psychosocial factors such as 'psychological demands' among men and 'job dissatisfaction' among women was associated with upper back pain. Regarding the 'psychological demands' factor, Engholm \& Holmström (2005) found similar results to those of this study, with the chance of upper back pain increasing by $24 \%$ due to high psychological demands. However, for 'job dissatisfaction' factor, the findings of Engholm \& Holmström (2005) suggest that this factor does not affect the risk of back pain. However, these authors did not separate their sample by gender, which may have masked the effect of job dissatisfaction in women. Dianat et al. (2015) concluded that low job satisfaction was a predictor of symptoms in the upper back.

\subsection{Symptoms in the regions of the upper limbs}

An analysis of the results revealed that the occurrence of WRMD pain symptoms in the shoulder was significantly associated with factors such as 'monotonous work' among men. Werner et al. (2005), and Widanarko et al. (2014) found no association between the 'monotony' factor and shoulder symptoms. The discrepancy in the results for this factor is related to the country in which each study was conducted; working conditions differ between the US and New Zealand. Lee et al. (2011) noted that workers' nationalities and acculturation were variables that were significantly associated with the occurrence of musculoskeletal injuries. Due to different working conditions, studies in European countries has shown significant differences in the effects of psychosocial factors (Niedhammer et al., 2012; Wahrendorf \& Siegrist, 2014; Lunau et al., 2015). For Lunau et al. (2017) 
employees in countries with a comprehensive psychosocial risk management policy report comparatively low levels of psychosocial risks. Most Brazilian footwear industries do not have psychosocial risk management policies.

Job dissatisfaction among women contributes to WRMD in the shoulders, elbows and wrists similar to those studies of Andersen et al. (2007), Yu et al. (2012), Yue et al. (2014) and Dianat et al. (2015). Therefore, job dissatisfaction is a risk factor for women.

The occurrence of WRMD symptoms in the hand/finger was associated with the factor 'stress' among men and 'discrimination' among women. As for the 'stress' factor, the findings of Gell et al. (2005) suggest that stress was significantly correlated with pain in the hand. No studies were found evaluating the relationship between the 'discrimination' factor and the occurrence of WRMD symptoms specifically in the hand, although Abbe et al. (2011) found that this factor led to the emergence of health problems related to body pain.

\subsection{Symptoms in the regions of the lower limb}

Among the regions evaluated in the lower limbs, the hip/thigh and knee regions had the fewest WRMD symptoms. Among men, only the 'bullying' and 'stress' factors were significantly associated with symptoms in the hip/thigh and knee regions, respectively. No studies were found evaluating the relationship between the 'bullying' factor and the risk of pain in the hip area, although Law et al. (2011) found that this factor was detrimental to the psychosocial environment in the workplace, an effect that could consequently trigger the onset of health problems. With regard to the 'stress' factor, Mehrdad et al. (2010) did not find sufficient evidence of a relationship between this factor and WRMD symptoms in the knee, although his findings have noted that 'stress' contributes to symptoms in the feet/ankles.

\subsection{Reason for the difference between genders}

Recent studies that have been conducted in China and France shown mostly women are more sensitive to psychosocial factors than men (Yu et al., 2012; Rigouin et al., 2014). The French study does not explain exactly the relationship that gender has in the development of WRMD due to psychosocial factors. But the Chinese study based on the findings of Jäger et al. (1991), Lundberg (2002), Hallin (2003), Norman et al. (2008), and Tornqvist et al. (2009) explains that these results regarding gender occur due to biological differences, in pain perception threshold, in methods of work, in exposure to risk and type of employment. Soon, two of these factors are related to the human organism and three to organizational factors. For organizational factors, studies of de Zwart et al. (2001) with workers the same occupational class, and Coury et al. (2002) with workers who perform the same function show that different results can be observed in men and women. Still on the organizational factors, Hooftman et al. (2009) affirm that exposure to different ways of doing the job is very small or obsolete when analyzed the set of variables present in the day's work. The same author also speaks of the variables related to the human organism, but believes that personal factors, such as the need to be present at home when a child is sick, are more relevant to women, contributing more significantly for the WRMD symptoms. In line with this, Mosaly (2016) found that individuals who have family problems are more likely to develop symptoms of WRMD in the upper limbs. For Roquelaure et al. (2002) the constraints imposed by work are much more important than the factors of biological order to explain the differences in gender in the relationship between psychosocial factors and WRMD. However, studies Clays et al. (2007) in Belgium, Ghaffari et al. (2008) in Iran, and Hooftman et al. (2009) in Netherlands show that men in many circumstances are more affected by psychosocial factors that women. The Belgian and Iranian study does not explain because the results are different for males and females. The Dutch study, in part, explains this difference in severity of symptoms reported where men tend to report fewer WRMD symptoms, but more severe and serious.

This study suggests that a larger number of psychosocial factors, such as 'psychological demands' and 'low social support from supervisors', influence on develop of WRMD in various regions of the body of the male workers, although these factors contribute a low impact in WRMD. On the other hand, a few psychosocial factors, such as the 'job dissatisfaction', increase the chance of WRMD more significantly in women. The results of Hooftman et al. (2009) are similar, because in the men a greater number of psychosocial factors were significantly associated with the onset of WRMD, although that the impact of most factors in increase chance is less than 40\%; unlike what occurred in women, where a smaller number of psychosocial factors were associated with WRMD, but the impact of most factors in increase the chance of musculoskeletal disorders is greater than 40\%. However, epidemiological studies with large populations still need to be done to explain with greater certainty the difference in results as to gender (Collins \& 0'Sullivan, 2015). 


\subsection{Limitations and future studies}

This study has some limitations. The first was no observation of workers in more than one point of time. Longitudinal studies could provide more solid conclusions about the relationship between psychosocial factors and the occurrence of symptoms of WRMD. The second limitation was not included factors in the models, such as biomechanical and environmental, so to better explain the impact of psychosocial factors at WRMD considering these factors together. Studies are needed to address those issues in the future. A third limitation is associated with collection data, which focuses on worker's perception and this can present a small distortion. The fourth limitation is that the sample is composed only by Brazilian workers. Therefore, future studies should be longitudinal with workers from several countries, jointly associating biomechanical, environmental and psychosocial risk factors to WRMD symptoms, and evaluating factors beyond the worker's perception.

\section{Conclusion}

This study found that psychosocial factors had an effect on the appearance of WRMD symptoms. The 'stress' was associated with the emergence of pain in some parts of the body in men, whereas the 'job dissatisfaction' factor was more strongly correlated with WRMD symptoms in women. This paper suggests that stress coping strategies are developed by the footwear industries focused on workers' emotions and work problem solving (Folkman \& Moskowitz, 2004), as these variables contribute to the relief of emotional distress, accepting responsibility, self-control, escape strategies and identification of specifics stressful (Folkman \& Lazarus, 1988; Dardas \& Ahmad, 2015). As for 'job dissatisfaction' changes in the organizational climate of footwear industries may reflect on important improvements in this factor (Rueda et al., 2012), since studies in this industrial sector have demonstrated the suffering experienced by workers (Borsoi et al., 2009; Rigotto et al., 2010; Silva et al., 2017). However, to initiate changes in companies, it would be necessary to have laws covering psychosocial risks, such as the Framework Directive 89/391/EEC; this declares that employers are obliged to ensure workers' health and to guarantee a safe and healthy work environment, both in terms of physical and psychosocial conditions at work (European Commission, 2001). It was concluded that a greater number of psychosocial factors influences the development of WRMD in male workers, although the effect these factors be discreet. In women, less psychosocial factors are related to WRMD; however, its influence is very significant, with increases of more than 70\% in the chance of WRMD for most psychosocial factors assessed.

\section{References}

Abbe, O. O., Harvey, C. M., lkuma, L. H., \& Aghazadeh, F. (2011). Modeling the relationship between occupational stressors, psychosocial/ physical symptoms and injuries in the construction industry. International Journal of Industrial Ergonomics, 41(2), 106-117. http:// dx.doi.org/10.1016/j.ergon.2010.12.002.

Aghili, M. M. M., Asilian, H., \& Poursafa, P. (2012). Evaluation of musculoskeletal disorders in sewing machine operators of a shoe manufacturing factory in Iran. The Journal of the Pakistan Medical Association, 62(3, Suppl 2), 20-25. PMid:22768452.

Amano, M., Umeda, G., Nakajima, H., \& Yatsuki, K. (1988). Characteristics of work actions of shoe manufacturing assembly line workers and a cross-sectional factor-control study on occupational cervicobrachial disorders. Japanese Journal of Industrial Health, 30(1), 3-12. PMid:3260299.

Andersen, J. H., Haahr, J. P., \& Frost, P. (2007). Risk factors for more severe regional musculoskeletal symptoms: a two-year prospective study of a general working population. Arthritis and Rheumatism, 56(4), 1355-1364. PMid:17393441. http://dx.doi.org/10.1002/ art.22513.

Azagba, S., \& Sharaf, M. F. (2011). Psychosocial working conditions and the utilization of health care services. BMC Public Health, 11(1), 642. PMid:21834974. http://dx.doi.org/10.1186/1471-2458-11-642.

Barbosa, R. E. C., Assunção, A. Á. A., \& De Araújo, T. M. (2013). Musculoskeletal pain among healthcare workers: an exploratory study on gender differences. American Journal of Industrial Medicine, 56(10), 1201-1212. PMid:23868813. http://dx.doi.org/10.1002/ ajim.22215.

Bathman, L. M., Almond, J., Hazi, A., \& Wright, B. J. (2013). Effort-reward imbalance at work and pre- clinical biological indices of ill-health: the case for salivary immunoglobulin A. Brain, Behavior, and Immunity, 33, 74-79. PMid:23743258. http://dx.doi. org/10.1016/j.bbi.2013.05.010.

Bernard, B.P. (1997). Musculoskeletal disorders and workplace factors: a critical review of epidemiologic evidence for work-related musculoskeletal disorders of the neck, upper extremity, and low back. Atlanta: CDC.

Borsoi, l. C. F., Rigotto, R. M., \& Maciel, R. H. (2009). Da excelência ao lixo: humilhação, assédio moral e sofrimento de trabalhadores em fábricas de calçados no Ceará. Cadernos de Psicologia Social do Trabalho, 12(2), 173-187. http://dx.doi.org/10.11606/issn.19810490.v12i2p173-187.

Brasil. Ministério da Previdência Social. (2013). Anuário estatístico de acidentes do trabalho 2013. Brasília: Ministério da Previdência Social. Retrieved in 19 December 2016, from http://www.previdencia.gov.br/dados-abertos/aeat- 2013/estatisticas-de-acidentesdo-trabalho-2013/subsecao-c-acidentes-do-trabalho-segundo-a- cid/tabelas-c-2013/ 
Clays, E., De Bacquer, D., Leynen, F., Kornitzer, M., Kittel, F., \& De Backer, G. (2007). The impact of psychosocial factors on low back pain longitudinal results from the belstress study. Spine, 32(2), 262-268. PMid:17224824. http://dx.doi.org/10.1097/01. brs.0000251884.94821.c0.

Collins, J. D., \& O’Sullivan, L. W. (2015). Musculoskeletal disorder prevalence and psychosocial risk exposures by age and gender in a cohort of office based employees in two academic institutions. International Journal of Industrial Ergonomics, 46, 85-97. http:// dx.doi.org/10.1016/j.ergon.2014.12.013.

Cordeiro, G. M., \& Demétrio, C. G. B. (2008). Modelos lineares generalizados e extensões. Piracicaba: USP.

Coury, H. J. C. G., Porcatti, l. A., Alem, M. E. R., \& Oishi, J. (2002). Influence of gender on work-related musculoskeletal disorders in repetitive tasks. International Journal of Industrial Ergonomics, 29(1), 33-39. http://dx.doi.org/10.1016/S0169-8141(01)00047-6.

Couto, H. A., \& Moraes, L. F. R. (2003). Novas perspectivas na prevenção dos distúrbios dolorosos dos membros superiores: o entendimento dos fatores de organização do trabalho e psicossociais envolvidos em sua origem. Revista Brasileira de Medicina do Trabalho, 1(1), 43-58.

Dardas, L. A., \& Ahmad, M. M. (2015). Coping strategies as mediators and moderators between stress and quality of life among parents of children with autistic disorder. Stress and Health, 31(1), 5-12. PMid:23868562. http://dx.doi.org/10.1002/smi.2513.

Descatha, A., Leclerc, A., Chastang, J.-F., \& Roquelaure, Y. (2004). Incidence of ulnar nerve entrapment at the elbow in repetitive work. Scandinavian Journal of Work, Environment \& Health, 30(3), 234-240. PMid:15250652. http://dx.doi.org/10.5271/sjweh.784.

Descatha, A., Roquelaure, Y., Evanoff, B., Mariel, J., \& Leclerc, A. (2007). Predictive factors for incident musculoskeletal disorders in an in-plant surveillance program. The Annals of Occupational Hygiene, 51(3), 337-344. http://dx.doi.org/10.1093/annhyg/mel080. PMid:17227777.

Dianat, 1., \& Salimi, A. (2014). Working conditions of Iranian hand-sewn shoe workers and associations with musculoskeletal symptoms. Ergonomics, 574), 602-611. PMid:24588329. http://dx.doi.org/10.1080/00140139.2014.891053.

Dianat, l., Kord, M., Yahyazade, P., Karimi, M. A., \& Stedmon, A. W. (2015). Association of individual and work-related risk factors with musculoskeletal symptoms among lranian sewing machine operators. Applied Ergonomics, 51, 180-188. PMid:26154216. http:// dx.doi.org/10.1016/j.apergo.2015.04.017.

Engholm, G., \& Holmström, E. (2005). Dose-response associations between musculoskeletal disorders and physical and psychosocial factors among construction workers. Scandinavian Journal of Work, Environment \& Health, 31(Suppl 2), 57-67.x PMid:16363448.

European Agency for Safety and Health at Work. (2008). Work-related musculoskeletal disorders: prevention report. Luxembourg: European Agency for Safety and Health at Work. Retrieved in 19 December 2016, from https://osha.europa.eu/en/tools-and-publications/ publications/reports/en_TE8107132ENC.pdf

European Agency for Safety and Health at Work. (2014). What are stress and psychosocial risks? Healthy workplaces manage stress. Luxembourg: European Agency for Safety and Health at Work. Retrieved in 19 December 2016, from http://hw2014.healthyworkplaces.eu/en/stress-and- psychosocial-risks/what-are-stress-and-psychosocial-risks

European Commission. (2001). Promoting a European framework for corporate social responsibility. Luxembourg: Office for Official Publications of the European Communities. Green paper. Retrieved in 19 December 2016, from http://europa.eu/rapid/pressrelease_DOC-01-9_en.pdf

Fernandes, E. H., \& Fernandes, J. H. M. (2011). Síndrome dolorosa miofascial em trabalhadores com LER/DORT. Revista Brasileira de Medicina do Trabalho, 9(1), 39-44.

Folkman, S., \& Lazarus, R. S. (1988). Manual for the ways of coping questionnaire. Palo Alto: Consulting Psychologists Press.

Folkman, S., \& Moskowitz, J. T. (2004). Coping: pitfalls and promise. Annual Review of Psychology, 55(1), 745-774. PMid:14744233. http://dx.doi.org/10.1146/annurev.psych.55.090902.141456.

Gell, N., Werner, R., Franzblau, A., Ulin, S. S., \& Armstrong, T. J. (2005). A longitudinal study of industrial and clerical workers: incidence of carpal tunnel syndrome and assessment of risk factors. Journal of Occupational Rehabilitation, 15(1), 47-55. PMid:15794496. http://dx.doi.org/10.1007/s10926-005-0873-0.

Ghaffari, M., Alipour, A., Farshad, A. A., Jensen, 1., Josephson, M., \& Vingard, E. (2008). Effect of psychosocial factors on low back pain in industrial workers. Occupational Medicine, 58(5), 341-347. PMid:18296687. http://dx.doi.org/10.1093/occmed/kqn006.

Govindu, N. K., \& Babski-Reeves, K. (2014). Effects of personal, psychosocial and occupational factors on low back pain severity in workers. International Journal of Industrial Ergonomics, 44(2), 335-341. http://dx.doi.org/10.1016/j.ergon.2012.11.007.

Greiner, B. A., \& Krause, N. (2006). Observational stress factors and musculoskeletal disorders in urban transit operators. Journal of Occupational Health Psychology, 11(1), 38-51. PMid:16551173. http://dx.doi.org/10.1037/1076-8998.11.1.38.

Gupta, A. D., \& Mahalanabis, D. (2006). Study of hand function in a group of shoe factory workers engaged in repetitive work. Journal of Occupational Rehabilitation, 16(4), 675-684. PMid:17103324. http://dx.doi.org/10.1007/s10926-006-9048-x.

Hallin, R. G. (2003). Pain more painful in women: gender perspective neglected in research on the biological mechanisms of pain. Lakartidningen, 100(46), 3738-3741. PMid:14655329.

Hannan, L. M., Monteilh, C. P., Gerr, F., Kleinbaum, D. G., \& Marcus, M. (2005). Job strain and risk of musculoskeletal symptoms among a prospective cohort of occupational computer users. Scandinavian Journal of Work, Environment \& Health, 31(5), 375-386. PMid:16273964. http://dx.doi.org/10.5271/sjweh.921.

Hauke, A., Flintrop, J., Brun, E., \& Rugulies, R. (2011). The impact of work-related psychosocial stressors on the onset of musculoskeletal disorders in specific body regions: A review and meta- analysis of 54 longitudinal studies. Work and Stress, 25(3), 243-256. http:// dx.doi.org/10.1080/02678373.2011.614069.

Hooftman, W. E., van der Beek, A. J., Bongers, P. M., \& van Mechelen, W. (2009). ls there a gender difference in the effect of workrelated physical and psychosocial risk factors on musculoskeletal symptoms and related sickness absence? Scandinavian Journal of Work, Environment \& Health, 35(2), 85-95. PMid:19337673. http://dx.doi.org/10.5271/sjweh.1316.

Hultin, H., Hallqvist, J., Alexanderson, K., Johansson, G., Lindholm, C., Lundberg, 1., \& Möller, J. (2011). Work-related psychosocial events as triggers of sick leave: results from a Swedish case- crossover study. BMC Public Health, 11(1), 175. PMid:21429193. http:// dx.doi.org/10.1186/1471-2458-11-175.

lavicoli, S., Natali, E., Deitinger, P., Maria Rondinone, B., Ertel, M., Jain, A., \& Leka, S. (2011). Occupational health and safety policy and psychosocial risks in Europe: the role of stakeholders' perceptions. Health Policy, 101(1), 87-94. PMid:20832135. http://dx.doi. $\operatorname{org} / 10.1016 /$ j.healthpol.2010.08.005. 
ljzelenberg, W., Molenaar, D., \& Burdorf, A. (2004). Different risk factors for musculoskeletal complaints and musculoskeletal sickness absence. Scandinavian Journal of Work, Environment \& Health, 30(1), 56-63. PMid:15018029. http://dx.doi.org/10.5271/sjweh.765.

Jäger, M., Luttmann, A., \& Laurig, W. (1991). Lumbar load during one-handed bricklaying. International Journal of Industrial Ergonomics, 8(3), 261-277. http://dx.doi.org/10.1016/0169-8141(91)90037-M.

Kääriäl, S., Leino-Arjasl, P., Rahkonenl, O., Lahtil, J., Lahelmal, E., \& Laaksonenl, M. (2011). Risk factors of sciatic pain: a prospective study among middle-aged employees. European Journal of Pain, 15(6), 584-590. PMid:21163676. http://dx.doi.org/10.1016/j. ejpain.2010.11.008.

Karasek, R., Gordon, G., Pietrokovsky, C., Frese, M., Pieper, C., Schwartz, J., Fry, L., \& Schirer, D. (1985). Job content instrument: questionnaire and user's guide. Los Angeles: University of Southern California.

Kortum, E., Leka, S., \& Cox, T. (2011). Perceptions of psychosocial hazards, work-related stress and workplace priority risks in developing countries. Journal of Occupational Health, 53(2), 144-155. PMid:21325734. http://dx.doi.org/10.1539/joh.010016.

Kuorinka, l. A. A., \& Forcier, L. (1995). Work-related musculoskeletal disorders (WMSDs): a reference book for prevention. Great Britain: Taylor \& Francis.

Kuorinka, l., Jonsson, B., Kilbom, A., Vinterberg, H., Biering-Sørensen, F., Andersson, G., \& Jørgensen, K. (1987). Standardised Nordic questionnaires for the analysis of musculoskeletal symptoms. Applied Ergonomics, 18(3), 233-237. PMid:15676628. http://dx.doi. org/10.1016/0003-6870(87)90010-X

Law, R., Dollard, M. F., Tuckey, M. R., \& Dormann, C. (2011). Psychosocial safety climate as a lead indicator of workplace bullying and harassment, job resources, psychological health and employee engagement. Accident: Analysis and Prevention, 43(5), $1782-1793$. PMid:21658506. http://dx.doi.org/10.1016/j.aap.2011.04.010.

Leclerc, A., Chastang, J. F., Niedhammer, l., Landre, M. F., \& Roquelaure, Y. (2004). Incidence of shoulder pain in repetitive work. Occupational and Environmental Medicine, 61(1), 39-44. PMid:14691271.

Lee, H., Ahn, H., Park, C. G., Kim, S. J., \& Moon, S. H. (2011). Psychosocial factors and work-related musculoskeletal disorders among southeastern asian female workers living in Korea. Safety and Health at Work, 2(2), 183-193. PMid:22953201. http://dx.doi. $\operatorname{org} / 10.5491 /$ SHAW.2011.2.2.183.

Leka, S., Jain, A., Widerszal-Bazyl, M., $\square$ ołnierczyk-Zreda, D., \& Zwetsloot, G. (2011). Developing a standard for psychosocial risk management: PAS 1010. Safety Science, 49(7), 1047-1057. http://dx.doi.org/10.1016/j.ssci.2011.02.003.

Lu, M.-L., Nakata, A., Park, J. B., \& Swanson, N. G. (2014). Workplace psychosocial factors associated with work-related injury absence: a study from a nationally representative sample of Korean workers. International Journal of Behavioral Medicine, 21(1), 42-52. PMid:23794229. http://dx.doi.org/10.1007/s12529-013-9325-y.

Lunau, T., Dragano, N., Siegrist, J., \& Wahrendorf, M. (2017). Country differences of psychosocial working conditions in Europe: the role of health and safety management practices. International Archives of Occupational and Environmental Health, 2017. In press. http://dx.doi.org/10.1007/s00420-017-1225-z. PMid:28432422.

Lunau, T., Siegrist, J., Dragano, N., \& Wahrendorf, M. (2015). The association between education and work stress: does the policy context matter? PLoS One, 10(3), e0121573. PMid:25812142. http://dx.doi.org/10.1371/journal.pone.0121573.

Lundberg, U. (2002). Psychophysiology of work: Stress, gender, endocrine response, and work-related upper extremity disorders. American Journal of Industrial Medicine, 41(5), 383-392. PMid:12071491. http://dx.doi.org/10.1002/ajim.10038.

Lundberg, U., Granqvist, M., Hansson, T., Magnusson, M., \& Wallin, L. (1989). Psychological and physiological stress responses during repetitive work at an assembly line. Work and Stress, 3(2), 143-153. http://dx.doi.org/10.1080/02678378908256940.

Maroco, J., \& Garcia-Marques, T. (2013). Qual a fiabilidade do alfa de Cronbach? Questões antigas e soluções modernas? Laboratório de Psicologia, 4(1), 65-90. http://dx.doi.org/10.14417//p.763.

Mehrdad, R., Dennerlein, J. T., Haghighat, M., \& Aminian, 0. (2010). Association between psychosocial factors and musculoskeletal symptoms among Iranian nurses. American Journal of Industrial Medicine, 53(10), 1032-1039. PMid:20568267. http://dx.doi. $\operatorname{org} / 10.1002 /$ ajim.20869.

Melin, B., \& Lundberg, U. (1997). A biopsychosocial approach to work-stress and musculoskeletal disorders. Journal of Psychophysiology, $11(3), 238-247$.

Moraes, P. W. T., \& Bastos, A. V. B. (2013). As LER/DORT e os Fatores Psicossociais. Arquivos Brasileiros de Psicologia, 65(1), 2-20. Retrieved in 19 December 2016, from http://pepsic.bvsalud.org/scielo.php?script=sci_arttext\&pid=S1809-52672013000100002

Mosaly, P. R. (2016). Multifactor association of job, individual and psychosocial factors in prevalence of distal upper extremity disorders and quantification of job physical exposure. International Journal of Industrial Ergonomics, 55, 40-45. http://dx.doi.org/10.1016/j. ergon.2016.07.005.

Nicot, A.-M. (2007). Industrial workers most exposed to job strain. Dublin: Eurofound. Retrieved in 19 December 2016, from http:// www.eurofound.europa.eu/observatories/eurwork/articles/industrial- workers-most-exposed-to-job-strain

Niedhammer, l., Sultan-Taïeb, H., Chastang, J.-F., Vermeylen, G., \& Parent-Thirion, A. (2012). Exposure to psychosocial work factors in 31 European countries. Occupational Medicine, 62(3), 196-202. PMid:22394680. http://dx.doi.org/10.1093/occmed/kqs020.

Norman, K., Floderus, B., Hagman, M., Toomingas, A., \& Tornqvist, E. W. (2008). Musculoskeletal symptoms in relation to work exposure at call center companies in Sweden. Work, 30(2), 201-214. PMid:18413936.

Petit, A., Ha, C., Bodin, J., Parot-Schinkel, E., Ramond, A., Leclerc, A., Imbernon, E., \& Roquelaure, Y. (2014). Personal, biomechanical, organizational and psychosocial risk factors for neck disorders in a working population. Journal of Occupational Health, 56(2), 134-140. PMid:24553623. http://dx.doi.org/10.1539/joh.13-0186-0A.

R Core Team. (2016). R: a language and environment for statistical computing. Vienna: R Foundation for Statistical Computing. Retrieved in 19 December 2016, from https://www.R-project.org/

Rigotto, R. M., Maciel, R. H., \& Borsoi, l. C. F. (2010). Produtividade, pressão e humilhação no trabalho: os trabalhadores e as novas fábricas de calçados no Ceará. Revista Brasileira de Saúde Ocupacional, 35(122), 217-228. http://dx.doi.org/10.1590/S030376572010000200005.

Rigouin, P., Ha, C., Bodin, J., Le Manac’h, A. P., Descatha, A., Goldberg, M., \& Roquelaure, Y. (2014). Organizational and psychosocial risk factors for carpal tunnel syndrome: a cross-sectional study of French workers. International Archives of Occupational and Environmental Health, 87(2), 147-154. PMid:23358663. http://dx.doi.org/10.1007/s00420-013-0846-0. 
Roquelaure, Y., Mariel, J., Fanello, S., Boissière, J.-C., Chiron, H., Dano, C., Bureau, D., \& Penneau-Fontbonne, D. (2002). Active epidemiological surveillance of musculoskeletal disorders in a shoe factory. Occupational and Environmental Medicine, 59(7), 452458. PMid:12107293. http://dx.doi.org/10.1136/oem.59.7.452.

Rueda, F. J. M., Santos, A. A. A., \& Lima, R. C. (2012). Relação entre satisfação no trabalho e clima organizacional: um estudo com trabalhadores. Boletín de Psicología, 62(137), 129-140.

Rugulies, R., \& Krause, N. (2005). Job strain, iso-strain, and the incidence of low back and neck injuries: a 7.5-year prospective study of San Francisco transit operators. Social Science \& Medicine, 61(1), 27-39. PMid:15847959. http://dx.doi.org/10.1016/j. socscimed.2004.11.042.

Serratos-Perez, J. N., \& Mendiola-Anda, C. (1993). Musculoskeletal disorders among male sewing machine operators in shoemaking. Ergonomics, 36(7), 793-800. PMid:8339719. http://dx.doi.org/10.1080/00140139308967943.

Siegel, J. H. (2007). Risk of repetitive-use syndromes and musculoskeletal injuries. Techniques in Gastrointestinal Endoscopy, 9(4), 200-204. http://dx.doi.org/10.1016/j.tgie.2007.08.010.

Siegrist, J. (1998). Adverse health effects of effort-reward imbalance at work: theory, empirical support, and implications for prevention. In C. L. Cooper (Ed.). Therories of organizational stress. New York: Oxford University Press.

Silva, J. M. N., Gontijo, L. A., Silva, L. B., Merino, E. A. D., Vieira, E. M. A., Leite, W. K. S., \& Torres, M. G. L. (2016). Avaliação da correlação entre fatores psicossociais e sintomas de DORT em colaboradores de uma indústria de calçados. Espacios, $37(31), 23$.

Silva, J. M. N., Vergara, L. L., Gontijo, L. A., Vieira, E. M. A., Leite, W. K. S., \& Torres, M. G. L. (2017). Análise do impacto do estresse causado pelas dores osteomusculares no desenvolvimento de novos Distúrbios Osteomusculares Relacionados ao Trabalho (DORTs). Espacios, 38(18), 9.

Smith, A., Johal, S., Wadsworth, E., Davey, G. D., \& Peters, T. (2000). The scale of occupational stress: the bristol stress and health at work study (CRR 265/2000). Norwich: Health and Safety Executive.

Solidaki, E., Chatzi, L., Bitsios, P., Markatzi, l., Plana, E., Castro, F., Palmer, K., Coggon, D., \& Kogevinas, M. (2010). Work related and psychological determinants of multi-site musculoskeletal pain. Scandinavian Journal of Work, Environment \& Health, 36(1), 54-61. PMid:20011982. http://dx.doi.org/10.5271/sjweh.2884.

Souza, S. F., Carvalho, F. M., Araújo, T. M., \& Porto, L. A. (2010). Fatores psicossociais do trabalho e transtornos mentais comuns em eletricitários. Revista de Saúde Pública, 44(4), 710-717. PMid:20676561. http://dx.doi.org/10.1590/S0034-89102010000400015.

Souza, S. F., Carvalho, F. M., Koifman, S., \& Porto, L. A. (2012). Depressão em trabalhadores de linhas elétricas de alta tensão. Revista Brasileira de Epidemiologia, 15(2), 235-245. PMid:22782089. http://dx.doi.org/10.1590/S1415-790X2012000200001.

Tornqvist, E. W., Hagberg, M., Hagman, M., Risberg, E. H., \& Toomingas, A. (2009). The influence of working conditions and individual factors on the incidence of neck and upper limb symptoms among professional computer users. International Archives of Occupational and Environmental Health, 82(6), 689-702. PMid:19205721. http://dx.doi.org/10.1007/s00420-009-0396-7.

Van den Heuvel, S. G., van der Beek, A. J., Blatter, B. M., Hoogendoorn, W. E., \& Bongers, P. M. (2005). Psychosocial work characteristics in relation to neck and upper limb symptoms. Pain, 114(1-2), 47-53. PMid:15733630. http://dx.doi.org/10.1016/j.pain.2004.12.008.

Wahrendorf, M., \& Siegrist, J. (2014). Proximal and distal determinants of stressful work: framework and analysis of retrospective European data. BMC Public Health, 14(1), 849. PMid:25127723. http://dx.doi.org/10.1186/1471-2458-14-849.

Warnakulasuriya, S. S. P., Peiris-John, R. J., Coggon, D., Ntani, G., Sathiakumar, N., \& Wickremasinghe, A. R. (2012). Musculoskeletal pain in four occupational populations in Sri Lanka. Occupational Medicine, 62(4), 269-272. PMid:22661663. http://dx.doi.org/10.1093/ occmed/kqs057.

Werner, R. A., Franzblau, A., Gell, N., Ulin, S. S., \& Armstrong, T. J. (2005). A longitudinal study of industrial and clerical workers: predictors of upper extremity tendonitis. Journal of Occupational Rehabilitation, 15(1), 37-46. PMid:15794495. http://dx.doi. org/10.1007/s10926-005-0872-1.

Widanarko, B., Legg, S., Devereux, J., \& Stevenson, M. (2014). The combined effect of physical, psychosocial/organisational and/or environmental risk factors on the presence of work-related musculoskeletal symptoms and its consequences. Applied Ergonomics, 45(6), 1610-1621. PMid:24934982. http://dx.doi.org/10.1016/j.apergo.2014.05.018.

Widanarko, B., Legg, S., Devereux, J., \& Stevenson, M. (2015). Interaction between physical and psychosocial work risk factors for low back symptoms and its consequences amongst Indonesian coal mining workers. Applied Ergonomics, 46(Pt A), 158-167. PMid:25151314. http://dx.doi.org/10.1016/j.apergo.2014.07.016.

Widanarko, B., Legg, S., Stevenson, M., Devereux, J., Eng, A., Mannetje, A., Cheng, S., Douwes, J., Ellison-Loschmann, L., McLean, D., \& Pearce, N. (2011). Prevalence of musculoskeletal symptoms in relation to gender, age, and occupational/industrial group. International Journal of Industrial Ergonomics, 41(5), 561-572. http://dx.doi.org/10.1016/j.ergon.2011.06.002.

Wijnhoven, H. A. H., de Vet, H. C. W., \& Picavet, H. S. J. (2006). Prevalence of musculoskeletal disorders is systematically higher in women than in men. The Clinical Journal of Pain, 22(8), 717-724. PMid:16988568. http://dx.doi.org/10.1097/01.ajp.0000210912.95664.53.

Yu, S., Lu, M.-L., Gu, G., Zhou, W., He, L., \& Wang, S. (2012). Musculoskeletal symptoms and associated risk factors in a large sample of Chinese workers in Henan province of China. American Journal of Industrial Medicine, 55(3), 281-293. PMid:22125090. http:// dx.doi.org/10.1002/ajim.21037.

Yu, S., Nakata, A., Gu, G., Swanson, N. G., He, L., Zhou, W., \& Wang, S. (2013). Job Strain, Effort- reward Imbalance and Neck, Shoulder and Wrist Symptoms among Chinese Workers. Industrial Health, 51(2), 180-192. PMid:23268836. http://dx.doi.org/10.2486/ indhealth.MS1233.

Yue, P., Xu, G., Li, L., \& Wang, S. (2014). Prevalence of musculoskeletal symptoms in relation to psychosocial factors. Occupational Medicine, 64(3), 211-216. PMid:24604101. http://dx.doi.org/10.1093/occmed/kqu008.

Zwart, B. C. H., Frings-Dresen, M. H. W., \& Kilbom, A. (2001). Gender differences in upper extremity musculoskeletal complaints in the working population. International Archives of Occupational and Environmental Health, 74(1), 21-30. PMid:11196077. http:// dx.doi.org/10.1007/s004200000188. 